\title{
The Perceptions of Tertiary Level Learners on the Use of Mobile App 'Balloon Vocabulary' in Improving Vocabulary for Reading Comprehension
}

\author{
Philip Wilson John \\ Management \& Science University, College Sarawak, Malaysia \\ Maslawati Mohamad \\ Faculty of Education, Universiti Kebangsaan Malaysia, Bangi, Malaysia \\ Siti Nur Diyana Mahmud \\ Faculty of Education, Universiti Kebangsaan Malaysia, Bangi, Malaysia \\ Nurul Izzati Md Fuad \\ International Languages Teacher Training Institute, Malaysia
}

\begin{abstract}
The challenges that the English as a Second Language (ESL) learners encounter during the reading process impede their reading comprehension. During the reading process, they need to pick up the information and stimulation around the text to comprehend it. Learners with a low vocabulary repertoire usually face difficulties to understand the lengthy text. Therefore, in this study, a mobile application labelled 'Balloon Vocabulary' was developed to help Ibanese tertiary learners to enjoy their reading and develop their vocabulary repertoire. This study employed a mixed-method approach that aimed to seek the perceptions of 125 tertiary level Iban learners on the usage of 'Balloon Vocabulary' towards improving their vocabulary repertoire. This study was also embarked to discover the learners' performance after they completed both pretest and post-test by using the application. Descriptive and inferential analyses were used to analyze the data. The qualitative data were analyzed and transcribed into themes. From the findings, the process of experiencing gamification and language games has led the learners to discover their skill related to vocabulary. Furthermore, their passion for learning was increased due to the involvement of technology in learning. This application is hoped to serve as a potential platform for learners to gain new experience dealing with new technological ways of learning English. Then, it will tread a new path for teachers as they will be able to attract learners' attention and realign their focus to achieve desired content in learning.
\end{abstract}

Index Terms - mobile application, reading, English as a second language, vocabulary, tertiary learners

\section{INTRODUCTION}

Intensive reading is always a challenge to English as a Second Language (ESL) learners especially when they have to read lengthy texts (Hamdan et. al 2017). Chandran and Shah (2019) have proposed how learners often neglected reading for other purposes and only focused on their studies only. Learners' perception would only change if only the reading strategy is organized in such a way that it triggers their attention to focus more on reading activity. This effect has been shown in a study done by Rahim et al. (2017) whereby learners who employed graphic elements in their text were likely to score better in the reading text compared to a group who practiced solely on reading text. Zhu et al. (2016) also consider this breakthrough as another educational value and innovative teaching that could be the game-changer in a reading lesson. Zhu et al. (2017) agreed that reading activity can be made easy as vocabulary enhancement can be done by using interesting methods such as using graphic enhancement or technological assistance.

Vocabulary learning is the pivotal element of achieving a goal in reading lessons. It is very crucial to have sufficient vocabulary knowledge when acquiring a second language like English. Ibrahim et al. (2016) has conducted research associated with vocabulary and they supported the idea that vocabulary is a vital component in language learning because it has to support the process of enhancing reading comprehension. This task can be challenging for the new learners as they need to adapt and progress well with their peers. Peters (2018) has been scrutinizing the figures studied by van Zeeland and Schmitt (2013) whereby they projected that language learners should know between 2000-3000 words families to reach a proficient level of 95\%. Peters (2018) then concluded that these figures reflect the demanding task that a learner has to undergo to reach a certain level of language proficiency. It is unlikely for the learners to 
acquire all these words in a language classroom alone due to time constraints. This is where Nation (2015) proposed a leading method of extensive reading to enrich learners' vocabulary. In his article, Nation (2015) stated that extensive reading will supply learners with continuous occurrences with unfamiliar words. He further argued that the unfamiliar words will be fostered by their mental capacity and the process ends when the words are searched in a dictionary. However, some young second language learners might not have the opportunity of experiencing such conditions due to limitations concerning their demographic background and cultural exposure (Kraut, Chandler \& Hertenstein, 2016). Therefore, many tertiary ESL learners are struggling to fulfill the reading task given to them. This problem is even worse especially during the Covid19 pandemic whereby learners are detached from face-to-face lessons as most of the lessons at the tertiary level are conducted online. Thus, the researchers should attempt to address the learners' difficulties in reading particularly due to their poor vocabulary repertoire and reading interest.

ESL teachers in Malaysia have now adopted a fun and interesting way to make certain of an exciting class (Morat, Shaari \& Abidin, 2016). They have progressively gone very well with the advancement of technology. Generation $Z$ learners prefer reading and vocabulary lessons that are integrated with ICT especially mobile learning (Azli, Shah, \& Maslawati, 2018). This would generate their motivation in learning (Gikas \& Grant, 2013). A study done by Umar and Hassan (2015) to 7320 teachers all over Malaysia has found that ICT could significantly influence learners' learning and improves the effectiveness of the lessons. In fact, according to Zou and $\mathrm{Li}$ (2015), mobile learning influences the mood of learners in the classroom as they consider this to be a good medium for learning English. At the institution where this study took place, first-year learners must enroll in two courses- English for General Purposes and English for Academic Enrichment. It is a compulsory course whereby they must pass this paper. At the end of this course, they would be equipped with reading strategies, dictionary skills, and related skills. These courses were chosen because the content of the syllabus had extensive opening remarks for vocabulary topics that will help them to answer the questions in the application. The Iban learners tend to treat the second language as their mother tongue. This language interference has made the reading process a bit of a daunting task to them. This claim however contradicts the study done by Kai and Hua (2021) whereby they claimed that the mother tongue can indeed assist learners if educators can manipulate the learner's mother tongue for optimizing the learning outcomes.

Learners' understanding seems to be contrasted when it comes to comprehending English text. According to the faculty record of this university, for three consecutive years (2016-2019), the performance of 125 learners on the reading test has shown a sharp increase in their cumulative average point. The integration of technology particularly mobile learning as classroom activities has resulted in the learners feeling motivated in learning. Nevertheless, it is quite challenging to maintain the ESL learners' commitment to learning since, for most of them, mobile phones are just a tool of entertainment. To tackle this problem, the researchers have developed a mobile app or 'Balloon Vocabulary' to spark and sustain the learners' interest and achieve the course objectives simultaneously. The learners were asked to complete the reading assignments uploaded in the app. Therefore, this study was embarked to answer two research questions:

1. What are the learners' experiences in learning through 'Balloon Vocabulary'?

2. How does the mobile app 'Balloon Vocabulary' affect learners' vocabulary?

\section{LITERATURE REVIEW}

\section{A. The Reading Models}

There are three underpinning models the researchers adopted in designing the activities in the mobile apps 'Balloon Vocabulary'. The reading models are bottom-up, top-down and interactive reading models.

The bottom-up approach can also be known as phonics, which allows the learners to match letters with sounds in an explained sequence. The reading in this context is a linear process whereby readers decode a text word by word or a single unit, linking words into phrases and then sentences. The bottom-up model also describes the information as a flow of series of stages that changes the input and passes it to the next stage without any feedback of future stages. This would result in the readers being passive recipients of the information in the text. The reader has to reproduce the meaning residing in the text. As for the context of ESL learners, the textbook is influenced by this situation that includes tasks that rely on the reader's comprehension without giving much attention to the reader's knowledge or experience on the subject matter. This is simply because activities are based on recognition of other subject matter. The learners of tertiary level in the institution where this study was conducted are keen on reading with the recognition of single words. From the single word, they would move on to identifying the rest of the content in the text to get the whole picture. Early frustration may be common at the first stage of reading because the unknown meaning of the words is the cause of the demotivation among the readers. As for the Iban learners especially, the spirit and determination may become weary after a few trials in reading because there is not enough support from peers and limited vocabulary to understand the reading passage.

Secondly, the concept of the top-down reading model. Reading is not just extracting meaning from a text but a process of connecting information in the text with the previous knowledge the reader brings to the act of reading (Pardede, 2008). In this situation, the readers' background will function as the main role in comprehending a test. The readers will undergo the process of hypothesis testing, whether to confirm or reject them by using their prior knowledge and relate it to the text they are reading.

In this study, interactive reading was practiced when the students use the app to develop their reading comprehension. 
Several studies have been conducted to measure the effects of interactive reading on learners' language development in L1 and L2 simultaneously (Davison \& Qi, 2017; Guiberson \& Ferris, 2019). The study of interactive reading was explained by Remy and Leroy (2016) and it can be defined as an instrument that focuses on encouraging printed stimulus and language development through storybooks while rendering the reading strategies explicit to enhance the understanding of a story. As claimed by Remy and Leroy (2016), interactive reading is widely used because it does not need large resources of printed materials and it can be adapted to cater to the needs of learners and communication styles. The mobile application 'Balloon Vocabulary' is adapted from printed materials that came from an extended reading activity in one of the topics taught in the class. The reading texts have been amended so that the content was made to be interactively interesting to Ibanese learners. The level of difficulties was lowered by simplifying the sentences. The given reading task is also tailor-made to the student's proficiency level. In order to sustain their reading interest, the app is infused with cultural Iban elements in the application namely the sape musical instrument and Iban cultural theme as the screen layout. This strategic way was hoped to make it appeal to the eyes and ears of the learners while sustaining the goals in reading lessons.

\section{B. Schemata Theory}

Schemata theory revolves around the background knowledge that the learners have and will eventually interact with the text. Schemata theory tests the learner's background knowledge interacts and responds to text and illustrations and deciphering them (Shin, Dronjic \& Park, 2019). This would be the fundamental role in the pursuit of comprehending a text if they can fully utilize their schemata or background knowledge. The notion of past experiences that lead to the creation of mental frameworks is called the schemata theory. Smith (1994) describes this theory as the "extensiveness representations of more general patterns or regularities that occur in our experience". Whatever the learners may read, it will relate to their past experiences that may include the knowledge of objects, situations, or events that will help the reader to organize and interpret information. It is emphasized that one has found a mental 'platform' if he has comprehended a text. The 'existing' home of the mental platform will be modified to accommodate that new input of knowledge. For ESL learners, they have nothing to refer to or link except the knowledge of the mother tongue. Due to their limited vocabulary repertoire of the second language, it is difficult to establish schemata knowledge. Therefore, some information transfer will occur from the L1 repertoire to the L2 setting. This results in the poor comprehensible quality of knowledge of the L2 and reading activity cannot achieve its full desirable result. As for Iban learners, the interference of the mother tongue is the main issue when it comes to understanding the reading text because they tend to treat the text as their L1 language.

As for ESL learners, they have to relate to the knowledge of their mother tongue in terms of linguistic features as well as culture (Maslawati, 2012). Due to their limited vocabulary repertoire of the English language, it is a challenge for them to fully understand all the words' meaning in a reading passage (Misbah, Melor, Maslawati \& Azizah, 2017) Therefore, according to them some information transfer and interferences will occur from L1 repertoire to L2 setting. This resulted in the poor comprehensible quality of knowledge of the L2 and reading activity cannot achieve its full desirable result. As for Iban learners, the interference of the mother tongue is the main issue when it comes to understanding the reading text because they tend to treat the text as their L1 language.

\section{Connectivism Theory}

George Siemens, the founder of connectivism theory, has paved a new model of learning which fits into the current context of the knowledge society. Siemens (2017) coins the term 'connectivism' because the Internet has made a huge paradigm shift in the education domain. Siemens (2017) describes that currently, knowledge could be obtained through multimedia and the internet is the source of the constant flow of information and people need to draw meaning from it. The evolution of learning theory has made it clear that being relevant to a digital society, connectivism is the end of the scheme of evolution which will bring shape to the future of knowledge. What intrigues the researcher about this theory is that learning is inevitable for learners and they will always learn new knowledge with what they have with the network. The activities that the learner does when they practice learning on ICT are just like expanding and building themselves, together with the current trend of the world in certain connected ways.

To what Siemens has assumed relating to connectivism learning theory, he postulates the following principles that made up the theory.

- Diversity of opinions will shape learning and knowledge

- Process of connecting specialized nodes and information sources is for learning to take place

- Learning can be stored in non-human appliances (Technology appliances)

- To ask more for what has been known is critical

- Connections must always be maintained to create a continuous learning facility

- Core skills are the ability to see connections between fields, ideas and concepts.

- The learner must have an autonomous decision in learning and be responsible for his outcome in learning.

The power of connectivism in the ESL classroom context brings a very similar situation to their learning process. In this study, the usage of mobile learning in the classroom is about the process of self-exploration and they need to connect their schemata to the learning materials found in the mobile apps known as 'Balloon Vocabulary'. The bridge of learning is required to optimize the input they receive via mobile apps. 


\section{Gamification and the Game Experience Questionnaire}

The game experience is defined as "an ensemble made up of the player's sensations, thoughts, feelings, actions, and meaning-making in a gameplay setting" (Ermi and Mayra, 2005). The experience that gamified service creates could ensure an effect on the gamification experience on the target behavior (Huotari \& Hamari 2017; Seaborn \& Fels 2015; Werbach 2014; Landers et al. 2018). Despite its relevance, gamification research is yet to fully establish the idea of the gameful encounter. There are just a few significant contributions to this construct, many of which are recent. One of the studies can be found in the case done by Landers et al. (2018), who formally described the experience as (a) perceiving that goals are not trivial and achievable; (b) a willingness to achieve these goals, but under restricting guidelines that the consumer is prepared to follow; and (c) a conviction that participation is voluntary. In ESL context, the participation by the learners is always voluntary. In fact, during the entire process of this study, the learners' positive response was yielded and sustained throughout their reading process and task completion. This also accords with the discussion made by Mahmud, Husnin and Soh (2020) in their study, which showed that gamification experience that the participants felt could lead to active engagement of the game and sustain their motivation in learning. They later hypothesized that the sense of teaching presence which was initially absent in the process of learning could be acknowledged through social interaction and scaffolding during the gamification process. The previous study on the process of interaction and scaffolding among peers was supported by Vygotsky (1978) and Dicheva et al. (2015) whereby both scholars stated that learning could be livelier and meaningful.

The questionnaire that was used for this study was adopted and developed from the Core Elements of the Gaming Experience Questionnaire (CEGE) or simply known as CEGE Questionnaire (Carvillo-Gamez, Cairns \& Cox, 2015) and was later revised and remodeled to GAMEX (Eppmann et al., 2018). The questionnaire was created with 14 items and they were divided according to three constructs or dimensions: Social Experience, Playfulness and Sensory Experience. The detailed explanation and definition of each construct will be explained below.

\section{Social Experience}

Social experience can be induced by competition (Vorderer et al., 2003). It is a game that takes up a different setting with the combination of socializing, relationship formation and teamwork (Yee 2006). As had been proposed by Rogers (2017), there was a piece of evidence whereby the feeling of togetherness happened when people playing mobile games. Furthermore, social activity has once been told that a gamer would experience a realistic condition as being in the actual one in the game.

\section{Playfulness}

The pleasurable behavior is voluntary and caused by fragments of imagination without being under the control of social and systematic rules.

\section{Sensory Experience}

A few authors claimed the sensory experience to include only visual (Wiebe et al., 2014 and Wyeth et al., 2012). However, Calvillo-Gámez et al. (2010) and Ermi and Mäyrä (2005) had disputed the claim that visuals must be accompanied by audio input. These variations are systematic nevertheless.

These constructs are important and it was set to be the foundation elements to develop the mobile application. Lately, second language learning has put more focus on gamification as the subject of interest by various researchers when the education scenario now has demanded technology to be embedded in classroom activities (Melor \& Hua, 2021). However, there are several limitations of the questionnaire designed for ESL Iban learners. One of the limitations is that the learners still could not figure out the meanings of the items asked in the questionnaire which prompted the assistance of researchers at all times. Another limitation came from the technical aspect of the mobile phone used during the activity. Some learners were still using the old and outdated smartphones and this caused retardation on the smoothness of the application to operate. As a result, a gameful experience could hardly be achieved and the questionnaire would be almost meaningless to them. Figure 1 is the snapshot of the mobile application activities which reflect the Sensory Experience. The visual and graphic stimulus presented in the application has aroused users (learners) to be engaged in more realistic feelings while completing the tasks. Tasks and the interface provided must resonate with excitement because this would trigger the learner's interest (Faiella \& Ricardi, 2015). The background of the interface portrays the legendary Iban warrior holding a cock in his arm while facing the black apparition (demon) from the afterlife. This sensory element brought a homey atmosphere to learners and this emulates the experience that they heard in classic Iban folklore during their childhood period. 


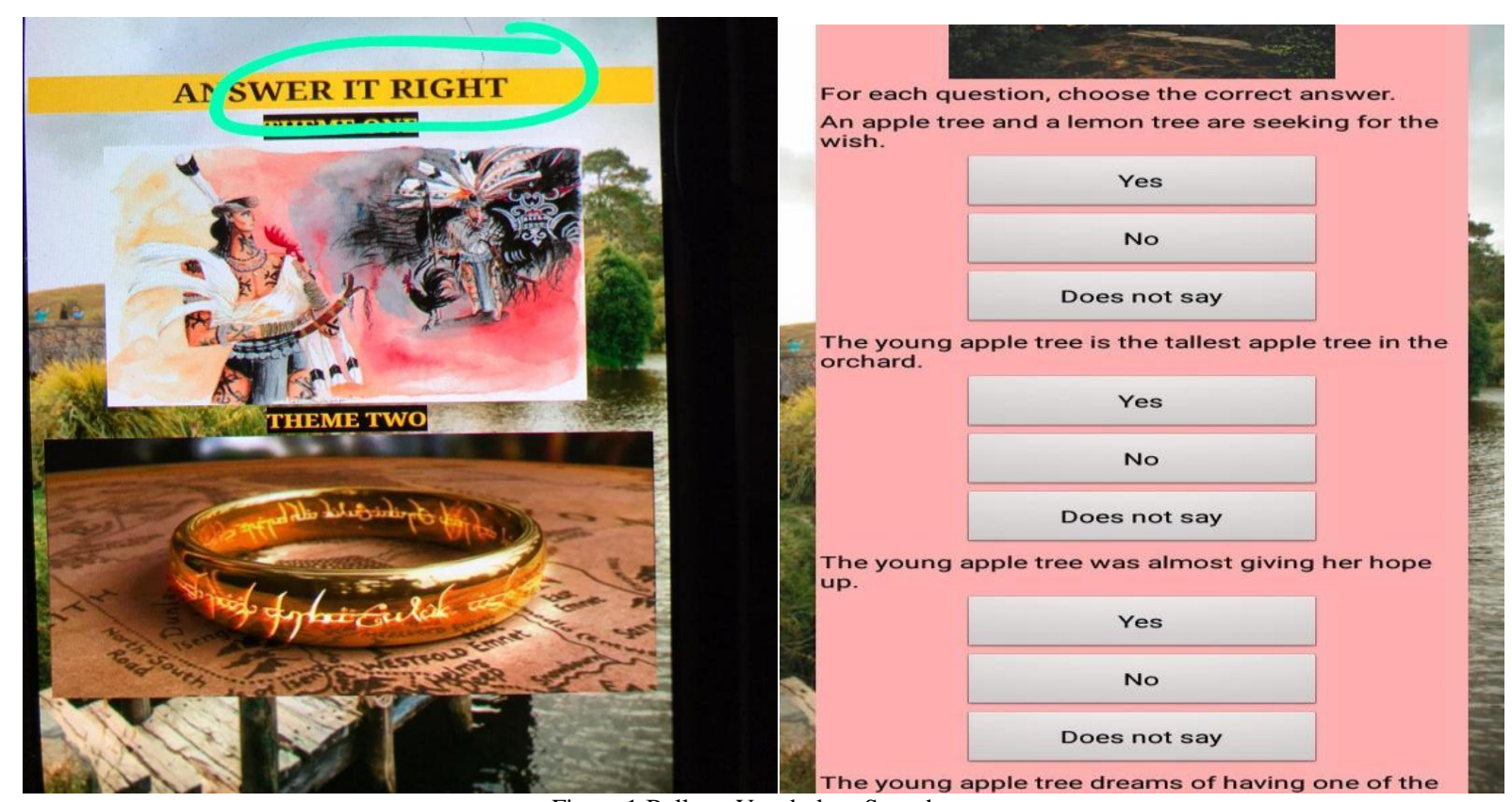

Figure 1 Balloon Vocabulary Snapshots

\section{METHODOLOGY}

\section{A. Research Design}

This study employed a mixed-method approach. A mixed-method approach is employed because according to Gibson (2017), a multi-source of data is best employed by using a mixed-method approach as it collects from both inside the focal entity and outside of the focal entity. Overlapping of variability can happen if the data is collected from a single course. Therefore, it is important to initiate the independence of data and avoid taking from a single-source data as it can lead to bias (Campbell \& Fiske, 1959). Creswell and Clerk (2011,p.8) also agreed to the significance of employing a mixed-method approach as they stated that "A mixed-method approach provides a better understanding of research problems than one approach only; in particular, those problems in which one data source may be insufficient, results need to be explained, exploratory findings need to be generalized, or a second method is needed to enhance a primary method, a theoretical stance needs to be employed, and an overall research objective can be best addressed with multiple phases or projects".

In this study, the researcher used four research instruments: semi-structured interviews, field notes, 'Balloon Vocabulary' evaluation (pre and post-test), and questionnaire. Table 1 shows the summary of the research methodology in this study.

TABLE 1

SUMMARY OF RESEARCH METHODOLOGY

\begin{tabular}{|l|l|l|l|}
\hline No. & Research Questions & Analysis & Instruments \\
\hline 1. & $\begin{array}{l}\text { What are the learners' experiences in learning } \\
\text { through 'Balloon Vocabulary'? }\end{array}$ & $\begin{array}{l}\text { Mean, SD, Percentage, } \\
\text { Thematic }\end{array}$ & $\begin{array}{l}\text { A questionnaire, Semi-structured Interview, } \\
\text { Field Notes }\end{array}$ \\
\hline 2 & $\begin{array}{l}\text { How does 'Balloon Vocabulary' affect learners' } \\
\text { vocabulary? }\end{array}$ & $\begin{array}{l}\text { (SPSS) } \\
\text { Inferential Statistics (T-tests) }\end{array}$ & Pre-test and Post-test \\
\hline
\end{tabular}

\section{B. Respondents}

\section{Iban learners, the Indigenous English Language Learners in Borneo}

Morgan (1968) describes Iban as the Sea Dayaks, who live in almost every part of Sarawak. They belong to the Proto-Malay group and are originally from Kapuas district in West Kalimantan of Indonesia. Currently, the Ibanese people in Sarawak, a part of Borneo Island, can be found scattered throughout the Sarawak state. At present, the population of Iban people flourishes throughout the island of Borneo, Malaysia. They move along well with modernization, just like others. In this study, the Ibanese learners who took part in this study reside around the city and neighboring division of Kuching. A total of 96\% (120) of the ESL learners have both Iban parents whereby the remaining $4 \%$ (5) have mixed parentage (either the mother or the father is an Iban). Although they are of mixed parentage, their upbringing is quite similar to those who have Iban as both parents. They can converse in the Iban language and share similar experiences in terms of culture, rituals and customs. They are undergraduate students with the age range between 21-23 years old. Most of them are in the intermediate proficiency level. 


\section{Sampling}

Purposive sampling was used in this case study because the researcher wanted to understand as much as possible from the subjects, as agreed by Creswell (2014). This group of participants was selected because they were able to meet the researchers' criteria. There were two criteria required in selecting the participants. One of the criteria was the learners must undertake a compulsory first and second-semester subject named English for General Purposes and English for Academic Enrichment respectively. These subjects were chosen because the content of the syllabus had extensive opening remarks for vocabulary lessons that require them to answer the comprehension and vocabulary questions in the application. Secondly, the learners that were chosen were all Iban, with at least either one of their parents is an Iban. The summary of the respondents and instruments used is shown in Table 2.

TABLE 2

SUMMARY OF THE RESPONDENTS AND RESEARCH INSTRUMENTS USED IN THIS STUDY

\begin{tabular}{|l|l|l|l|}
\hline No. & Instruments & Analysis & Respondents \\
\hline 1. & Questionnaire & Mean, SD, Percentage & 125 learners \\
\hline 2 & Field notes observation & Thematic & 125 learners \\
\hline 3 & Semi-structured Interview & Thematic & 5 learners \\
(A1, A2, A3, A4 \&A5)
\end{tabular}

\section{Research Instruments}

The researchers employed four research instruments in this study: researcher's field notes, semi-structured interview, questionnaire and Balloon Vocabulary pre-test and post-test. The semi-structured interview was categorized into 14 sub-themes and they were divided according to three constructs or dimensions: Social Experience, Playfulness and Sensory Experience

\section{Instrument Internal Reliability}

The Cronbach Alpha reliability index was used to determine the reliability of the instruments. The study drawn by Jackson (2006) stated that reliability is an important indication that proves the stability and congruency of the intended measuring instrument. Table 3 shows the reliability values that indicate the high reliability of a measure.

TABLE 3

CRONBACH AlPha VALUE

\begin{tabular}{cc}
\multicolumn{2}{c}{ CRONBACH ALPHA VALUE } \\
\hline Alpha Value & Reliability Level \\
\hline $.70-1.00$ & Strong \\
$.30-.69$ & Moderate \\
$00-.29$ & Weak \\
\hline
\end{tabular}

If the above table is referred to, a good value of internal consistency will yield Cronbach alpha with a coefficient value of 0.7 and above. From the pilot test conducted earlier, the result yielded a very favorable value which is 0.89 . Table 3.4 shows the Cronbach Alpha value for each construct.

TABLE 4

CRONBACH ALPHA VALUE FOR EACH CONSTRUCT

\begin{tabular}{lcc}
\hline Constructs & No. Of Items & Cronbach Alpha \\
\hline Social Experience & 5 & .89 \\
Playfulness & 5 & .81 \\
Sensory Experience & 4 & .82 \\
Total & $\mathbf{1 4}$ & .89 \\
\hline
\end{tabular}

\section{Internal Validity}

The items of the questionnaire were reviewed and validated by three experts in the field of study. The first expert is the Head of Department of the university's main campus. The second expert is a senior lecturer of the same university who has taught English for more than 25 years. The third expert has 10 year-experience as an English paper examiner. All the items in the questionnaire were validated and accepted with minor corrections on the grammar and question ambiguity. Upon the completion of the validity process, the questionnaire was further tested in a pilot study.

In order to test the internal validity of the application, 10 learners were asked to describe their experiences in a test run concerning different elements in the content. By including all the suggestions, comments and questions, the researcher aimed to cover enough game design elements that can afford sufficient scope of different experiences to create an application model that is friendly and interesting. These categories include the choice of traditional Iban music, stories/theme, difficulty level and language. As an example, the word "initiate" was asked by every learner during the test run. Therefore, the word was replaced with a similar meaning - "to begin".

\section{FINDINGS AND DiscUSSION}


The semi-structured interview responses of learners' experiences on using the mobile application, 'Balloon Vocabulary' are categorized into three themes or constructs: Social Experience, Playfulness, Sensory Experience. Next, the findings on the analysis of the paired sample t-test were also computed.

\section{RQ1: What are the learners' experiences in learning through 'Balloon Vocabulary'?}

\section{A. Social Experience}

Table 1 shows the findings of the questionnaire items which focus on their social experience while using the 'Balloon Vocabulary'. The highest score was obtained by Item 3, 'I do not feel threatened because other learners do not know me as the player' (Mean $=4.67)$ whereby $99.8 \%$ (121 participants) agreed to the statement. The smallest value of mean recorded for item 2, 'I feel closer when doing an activity with my friends' (Mean $=4.28$.) or 80\% (100 participants) agreed to the statement.

These findings are clearly in proportion with Zou and Li's (2015) findings whereby the respondents were happy when using mobile apps in learning vocabulary. They claimed that mobile phone learning is a good medium for learning as they are more engaged in the activities. Furthermore, the background music is relaxing and the features are user-friendly.

Additionally, the findings are also parallel with the Socio-constructivism theory proposed by Vygotsky (1978) whereby it is explained that learners can benefit from the L2 acquisition process with the presence of more skilled individuals or peers that could assist them in their task completion. In this study, the respondents enjoyed the task completion with the assistance of other classmates. In other words, these activities increased and sustained their motivation as well. Furthermore, they did not feel pressured or threatened because their identity was not revealed to others throughout the games.

\begin{tabular}{|c|c|c|c|c|c|c|c|}
\hline \multirow{3}{*}{ No. } & \multicolumn{7}{|c|}{ TABLE 5} \\
\hline & Item & $\begin{array}{l}\text { Strongly } \\
\text { Disagree }\end{array}$ & Disagree & Neutral & Agree & $\begin{array}{c}\text { Strongly } \\
\text { Agree }\end{array}$ & Mean \\
\hline & & $\%$ & $\%$ & $\%$ & $\%$ & $\%$ & \\
\hline 1. & $\begin{array}{l}\text { I love doing an activity } \\
\text { with my friends }\end{array}$ & $0.8(1)$ & $3.2(4)$ & $4.0(5)$ & $28.8(36)$ & $63.2(79)$ & 4.50 \\
\hline 2. & $\begin{array}{l}\text { I feel closer when doing } \\
\text { an activity with my } \\
\text { friends }\end{array}$ & $0.8(1)$ & $5.6(7)$ & $13.6(17)$ & $24.8(31)$ & $55.2(69)$ & 4.28 \\
\hline 3. & $\begin{array}{l}\text { I do not feel threatened } \\
\text { because other learners do } \\
\text { not know me as the } \\
\text { player. }\end{array}$ & $0.8(1)$ & $1.6(2)$ & $0.8(1)$ & $23.2(29)$ & $73.6(92)$ & 4.67 \\
\hline 4. & $\begin{array}{l}\text { I like the usage of } \\
\text { pseudonyms because } \\
\text { other learners do not } \\
\text { know the real me. }\end{array}$ & $2.4(3)$ & $3.2(4)$ & $8.0(10)$ & $16.0(20)$ & $70.4(88)$ & 4.49 \\
\hline 5. & $\begin{array}{l}\text { I enjoy receiving } \\
\text { motivation from my } \\
\text { friends because they will } \\
\text { cheer for me }\end{array}$ & $1.6(2)$ & $1.6(2)$ & $3.2(4)$ & $29.6(37)$ & $64.0(80)$ & 4.53 \\
\hline 6. & $\begin{array}{l}\text { I like my friends helping } \\
\text { me and guide me to } \\
\text { achieve my goals }\end{array}$ & $1.6(2)$ & $1.6(2)$ & $5.6(7)$ & $32.8(41)$ & $58.4(73)$ & 4.45 \\
\hline
\end{tabular}

Key: (Mean value) 1- Strongly Disagree, 2- Disagree, 3- Neutral, 4- Agree, 5- Strongly Agree

The data from the questionnaire were also confirmed by the semi-structured interview responses of five participants.

The interview question that was posed is:

1. Did you have fun when using the 'Balloon Vocabulary' with your friends?

One of the respondents, (A2), was delighted to know her score almost instantaneously after playing the application. She was impressed with how fast the game analyzed her answer and provided the score almost instantaneously.

'Every time I finish the game, I know my score right away. Very fast!'

From one of the researcher's field notes, he noted that most participants were smiling when playing the game and the expression of joy could be seen on their faces. This shows active and positive engagement from the learners as they felt content with the achievement. Furthermore, they bragged about their triumph feelings to others which was a good indicator of the good outcome from the game.

\section{B. Playfulness}

Table 6 shows the findings of the questionnaire items on the construct 'playfulness' while experiencing the 'Balloon Vocabulary'. The highest score was obtained by item 5, 'I love it when playing an active game' $($ Mean $=4.57$ ) whereby $92 \%$ (115 participants) agreed to the statement. The lowest mean score was obtained from item 1 which is 'I love it because I can learn new things' (Mean $=4.18$ ) or 73.6\% (92 participants) agreed to the statement. Previous studies have shown a great deal of support to these findings and one of them was done by Dicheva et al. (2015). They 
stated that games and interactive learning applications invigorate the learning atmosphere to be livelier and more motivated. Faiella and Ricciardi (2015) were also in agreement with these findings and they claimed that learning tasks can simply be transformed from ponderous to exciting and vibrant ones.

TABLE 6

LEARNERS' PLAYFULNESS EXPERIENCE ON 'BALLOON VOCABULARY'

\begin{tabular}{|c|c|c|c|c|c|c|c|}
\hline No. & Item & $\begin{array}{l}\text { RS' PLAYFU } \\
\text { Strongly } \\
\text { Disagree }\end{array}$ & $\begin{array}{l}\text { PERIENCE } \\
\text { Disagree }\end{array}$ & $\begin{array}{l}\text { LOON VOC } \\
\text { Neutral }\end{array}$ & $\begin{array}{l}\text { RY' } \\
\text { Agree }\end{array}$ & $\begin{array}{c}\text { Strongly } \\
\text { Agree }\end{array}$ & Mean \\
\hline & & $\%$ & $\%$ & $\%$ & $\%$ & $\%$ & \\
\hline 1. & $\begin{array}{l}\text { I love it because I can } \\
\text { learn new things. }\end{array}$ & $2.4(3)$ & $6.4(8)$ & $17.6(22)$ & $17.6(22)$ & $56.0(70)$ & 4.18 \\
\hline 2. & $\begin{array}{l}\text { I feel enjoyed when } \\
\text { doing this activity }\end{array}$ & $0.8(1)$ & $1.6(2)$ & $5.6(7)$ & $24.8(31)$ & $67.2(84)$ & 4.56 \\
\hline 3. & $\begin{array}{l}\text { I enjoy the positive } \\
\text { reinforcement given in } \\
\text { the 'Balloon } \\
\text { Vocabulary' }\end{array}$ & $1.6(2)$ & $6.4(8)$ & $16.0(20)$ & $17.6(22)$ & $58.4(73)$ & 4.25 \\
\hline 4. & $\begin{array}{l}\text { Funny memes make it } \\
\text { fun to use 'Balloon } \\
\text { Vocabulary'. }\end{array}$ & $3.2(4)$ & $8.0(10)$ & $2.4(3)$ & $14.4(18)$ & $72.0(90)$ & 4.44 \\
\hline 5. & $\begin{array}{l}\text { I love it when playing an } \\
\text { active game. }\end{array}$ & $1.6(2)$ & $2.4(3)$ & $2.4(3)$ & $24.8(31)$ & $68.8(86)$ & 4.57 \\
\hline
\end{tabular}

The respondents felt thrilled when they attempted the game. They felt excited because of the positive reinforcement that they received upon the completion of every task in the game application. Furthermore, the fun continued when they experienced funny memes displayed on the application. This statement is derived from the interview responses to the question: 'Did you experience any pleasurable moments while attempting to play the game?'

There was one learner, A2, who expressed the practicality of having the application in the classroom because it enabled them to perform multi-task activity which was learning and playing ("It was awesome! Two things done in one time- learning and playing!"). From the researcher's field notes, it was documented that their eyes were glued to their phone screen from the beginning of the game until the end.

Another learner (A3) seemed to be very excited when she discovered how lovely the memes were on the application. From the field notes, the learner looked mesmerized by the images displayed on her phone screen.

"(Burst in laughter) The memes are so funny la. And cute some more"

Next, another learner (A4) emphasized the fashionable and sophisticated way the application looked like. She even demanded to experience another application that was similarly exciting ("Cool! Very cool...like super cool, Sir. Make one game more please”). From the researcher's field notes, most of the learners expressed happiness by smiling throughout the activity. In conclusion, the explorative aspect in the game had provided a "mystery" element to the learner which increased the pleasurable aspect of the activity. Besides, they were able to create room for imagination and creativity throughout the game.

\section{Sensory Experience}

Table 7 shows the findings of questionnaire items that highlighted their sensory experiences while using the 'Balloon Vocabulary'. The highest mean score is by Item 3, 'The graphics and colors are visually pleasing' (Mean=4.71) whereby 96\% (120 participants) agreed to the statement. The least value of score recorded by item 4, 'The layout graphic design is suitable for my age' (Mean=4.24) or 86.4\% (108 participants) agreed to the statement. When the respondents attempted the application, most of their responses were very favorable. The graphic portrayed a huge cultural value to the Iban learners as the background showed the image of the legendary Iban warrior. Furthermore, the impact of background music proves to be utterly satisfying.

The study carried out by Zou and Li (2015) supports the findings of this study findings. Zou and Li (2015) explored the area of the effectiveness of mobile applications to learners' sensory learning and their results were positive. They discovered that the learners' interest became intensified when they used the technology in their learning. The learners were entertained by the application's graphic layout. They loved the combination of graphics and colors and this produced a pleasing sensory moment. The game layout design was appropriate to their taste. 


\begin{tabular}{|c|c|c|c|c|c|c|c|}
\hline \multirow{3}{*}{ No. } & \multirow{3}{*}{ Item } & \multicolumn{4}{|c|}{$\begin{array}{l}\text { TABLE } 7 \\
\text { EXPERIENCE ON 'BALLOON VOCABULARY' }\end{array}$} & \multirow{3}{*}{$\underset{\%}{\text { Strongly Agree }}$} & \multirow[b]{2}{*}{ Mean } \\
\hline & & $\begin{array}{l}\text { Strongly } \\
\text { Disagree }\end{array}$ & Disagree & Neutral & Agree & & \\
\hline & & $\%$ & $\%$ & $\%$ & $\%$ & & \\
\hline 1. & $\begin{array}{l}\text { I enjoy the music } \\
\text { background. }\end{array}$ & $3.2(4)$ & $0.8(1)$ & $9.6(12)$ & $16.8(21)$ & $69.6(87)$ & 4.49 \\
\hline 2. & $\begin{array}{l}\text { The interface is user } \\
\text { friendly }\end{array}$ & $1.6(2)$ & $0.8(1)$ & $3.2(4)$ & $28.8(36)$ & $65.6(82)$ & 4.56 \\
\hline 3. & $\begin{array}{l}\text { The graphics and } \\
\text { colors are visually } \\
\text { pleasing. }\end{array}$ & $2.4(3)$ & $0.8(1)$ & $0.8(1)$ & $15.2(19)$ & $80.8(101)$ & 4.71 \\
\hline 4. & $\begin{array}{l}\text { The layout graphic } \\
\text { design is suitable to } \\
\text { my age }\end{array}$ & $1.6(2)$ & $0.8(1)$ & $11.2(14)$ & $44.8(56)$ & $41.6(52)$ & 4.24 \\
\hline 5. & $\begin{array}{l}\text { The font type and size } \\
\text { look attractive. }\end{array}$ & $2.4(3)$ & $3.2(4)$ & $8.0(10)$ & $21.6(27)$ & $64.8(81)$ & 4.43 \\
\hline
\end{tabular}

The data was then triangulated by other interview question responses. The question was: How did you visually describe the experience using the 'Balloon Vocabulary'?

One of the learners, A1, expressed her joy when she described the graphics and colors displayed on the application (" "The colors..wahh..colorful and happy"). The next learner (A3) had somewhat reminisced about her hometown when she listened to the background 'Sape' music in the application in which she enjoyed it very much ('The song I like the 'Sape' sound. It reminds me of my longhouse'). The researcher's field notes indicate that the learners were surprised to listen to the Sape instrumental music. They could not believe that their cultural song was embedded in the game. In summary, the games themselves offer a purely aesthetic value and sense of ownership to them. The music, the sound, the graphics and the storyline were all very close to their heart.

\section{Findings Learners' Experiences in Learning through 'Balloon Vocabulary'}

Inferential statistics were used to analyze the performance of learners' vocabulary levels through the application. Before the test was given, the process of learners' familiarization with the application was applied to avoid any complications during the actual process. The learners have used the app multiple times. This would enable them to be mentally ready and also ensure their mobile devices are functioning well. Two tests were given namely pre-test and post-test. There were 125 learners of ESL Iban tertiary learners involved in the tests. Before performing the paired sample t-test, a normality test was performed first between the two scores (Pre-Test and Post-Test) to examine the distribution of the data. After the test was conducted, according to the Shapiro-Wilk distribution of normality, the pvalues $(\mathrm{p}=0.338)$ for the pre-test and post-test are greater than the Alpha value $(\mathrm{p}=0.05)$ which signifies that the scores data are normally distributed. According to Table 4.4, there was a significant difference between the mean of the PreTest and Post Test, $\mathrm{t}(124)=0.00, \mathrm{p}<0.05$. This shows that the learners' vocabulary performance has improved significantly. The findings concur with Isa et al.'s findings that (2011) showed that online games via mobile applications could change the teaching and learning atmosphere - enhance learners' language skills especially in ESL classroom learning.

TABLE 8

PAIRED SAMPLE T-TEST ON 'BALlOON VOCABULARY'

\begin{tabular}{|c|c|c|c|c|c|c|c|c|c|}
\hline \multicolumn{10}{|c|}{ Paired Differences } \\
\hline & & \multirow[b]{2}{*}{ Mean } & \multirow[b]{2}{*}{$\begin{array}{l}\text { Std. } \\
\text { Deviation }\end{array}$} & \multirow[b]{2}{*}{$\begin{array}{l}\text { Std. } \\
\text { Mean }\end{array}$} & \multicolumn{2}{|c|}{\begin{tabular}{llr}
$95 \%$ & \multicolumn{2}{l}{ Confidence } \\
Interval & of & the \\
Difference & &
\end{tabular}} & \multirow[b]{2}{*}{$\mathbf{t}$} & \multirow[b]{2}{*}{ df } & \multirow[b]{2}{*}{$\begin{array}{l}\text { Sig. } \\
\text { tailed) }\end{array}$} \\
\hline & & & & & Lower & Upper & & & \\
\hline Pair 1 & $\begin{array}{l}\text { Score on } \\
\text { Test before } \\
\text { Treatment- } \\
\text { Score on } \\
\text { Test after } \\
\text { Training }\end{array}$ & -1.944 & 2.519 & .225 & -2.390 & -1.500 & -8.630 & 124 & .000 \\
\hline
\end{tabular}

\section{CONCLUSION AND RECOMMENDATIONS}

Based on the findings of this study, it could be concluded that 'Balloon Vocabulary' is a useful online game tool and user-friendly in which most learners could benefit from playing it. Learners could perform better in vocabulary and reading when they are engaged in technology and perform collaborative learning with others. This application could promote a fun and active learning experience as it increases learners' social experience, playfulness and sensory experience in completing the task. Furthermore, it enhances learners' learning ability to solve problems in vocabulary learning. 
It is hoped that the government and authorities could consider slotting more time for the integration of mobile learning in English language classrooms since the young learners are more engaged in learning through mobile learning. Therefore, it is recommended for the teachers to utilize relevant mobile language games applications as their teaching materials to cater to Generation $\mathrm{Z}$ interests.

The 'Balloon Vocabulary' application has tremendous potential to promote active learning at all stages of education level. Therefore, further studies on different demographic backgrounds of learners, other language skills such as listening, writing and skills should be carried out. Therefore, further information on how this application can be used to enhance other learners' language learning experience could be explored. In conclusion, the use of 'Balloon Vocabulary' is beneficial as it gives a positive impact on Ibanese tertiary learners' vocabulary and reading comprehension level.

\section{ACKNOWLEDGMENTS}

This study is funded by a grant from the Faculty of Education, Universiti Kebangsaan Malaysia (GG-2020-015).

\section{REFERENCES}

[1] Calvillo-Gámez, E. H., \& Cairns, P. (2008). Pulling the strings: A theory of puppetry for the gaming experience. Conference Proceeding of the Philosophy of Computer Games

[2] Chandran, Y., \& Shah, P. M. (2019). Identifying learners' difficulties in ESL reading comprehension. Creative Education Journal, 10(13), 3372-3384.

[3] Creswell, J. W. (2014). A concise introduction to mixed methods research. SAGE publications. Los Angeles.

[4] Crystal Callista Anak Yunus; Tan Kim Hua (2021). Exploring Gamified Learning Tool in ESL Classroom: The Case of Quizizz. Journal of Education and e-Learning Research, 8(1): 103- 108.

[5] Davison, M. D., \& Qi, C. H. (2017). Language teaching strategies for preschool English learners. Perspectives of the ASHA Special Interest Groups, 2(1), 170-178

[6] Dicheva, D., Dichev, C., Agre, G., \& Angelova, G. (2015). Gamification in education: A systematic mapping study. Journal of Educational Technology \& Society, 18(3), 75-88

[7] Ermi, L., \& Mäyrä, F. (2005). Fundamental components of the gameplay experience: Analysing immersion. Worlds in play: International perspectives on digital games research, 37(2), 37-53.

[8] Eppmann, R., Bekk, M., \& Klein, K. (2018). Gameful experience in gamification: Construction and validation of a gameful experience scale [GAMEX]. Journal of Interactive Marketing, 43, 98-115.

[9] Faiella, F., \& Ricciardi, M. (2015). Gamification and learning: a review of issues and research. Journal of e-Learning and Knowledge Society, 11(3), 13-21 .

[10] Gibson, C. B. (2017). Elaboration, generalization, triangulation, and interpretation: On enhancing the value of mixed-method research. Organizational Research Methods, 20(2), 193-223.

[11] Gikas, J., \& Grant, M. M. (2013). Mobile computing devices in higher education: Student perspectives on learning with cellphones, smartphones \& social media. The Internet and Higher Education, 19, 18-26.

[12] Guiberson, M., \& Ferris, K. P. (2019). Early language interventions for young dual language learners: A scoping review. American journal of speech-language pathology, 28(3), 945-963.

[13] Huotari, K., \& Hamari, J. (2017). A definition for gamification: anchoring gamification in the service marketing literature. Electronic Markets, 27(1), 21-31.

[14] Ibrahim, E. H. E., Sarudin, I., \& Muhamad, A. J. (2016). The Relationship between Vocabulary Size and Reading Comprehension of ESL Learners. English Language Teaching, 9(2), 116-123.

[15] Kraut, R., Chandler, T., \& Hertenstein, K. (2016). The interplay of teacher training, access to resources, years of experience and professional development in tertiary ESL reading teachers' perceived self-efficacy. Gist: Education and Learning Research Journal, (12), 132-151

[16] Landers, R. N., Auer, E. M., Collmus, A. B., \& Armstrong, M. B. (2018). Gamification science, its history and future: Definitions and a research agenda. Simulation \& Gaming, 49(3), 315-337.

[17] Maslawati, M. (2012). Hypermedia reading environment for adult learners: a case study at Universiti Kebangsaan Malaysia. Unpublished Ph.D. Thesis, Universiti Kebangsaan Malaysia

[18] Mahmud, S. N. D., Husnin, H., \& Tuan Soh, T. M. (2020). Teaching Presence in Online Gamified Education for Sustainability Learning. Sustainability, 12(9), 3801.

[19] Misbah, N. H., Mohamad, M., Yunus, M. M., \& Ya'acob, A. (2017). Identifying the Factors Contributing to Students' Difficulties in the English Language Learning. Creative Education Journal, 8(13), 1999-2008.

[20] Morat, B. N., Shaari, A., \& Abidin, M. J. Z. (2016). Facilitating ESL Learning Using Youtube: Learners'motivational Experiences. Organized by: Association of Malaysian Researchers and Social Services Faculty of Teacher Training and Education, Universitas Syiah Kuala, Darussalam, Banda Aceh, 23, 137.

[21] Morgan, S. (1968). Iban aggressive expansion: some background factors. Sarawak Museum.

[22] Nation, P. (2015). Principles guiding vocabulary learning through extensive reading. Reading in a Foreign Language, 27 (1), 136-145.

[23] Pardede, P. (2008). A Review on Reading Theories and its Implication to the Teaching of Reading. UKI: ELT'n Edu A cyber ELT \& Edu service from Universitas Kristen Indonesia

[24] Peters, E. (2018). The effect of out-of-class exposure to English language media on learners' vocabulary knowledge. ITLInternational Journal of Applied Linguistics, 169(1), 142-168.

[25] Rahim, P. R. M. A., Yusuf, F., \& Dzulkafly, Z. (2017). Facilitating Reading Comprehension among ESL Learners Using Graphic Organizers. Malaysian Journal of ELT Research, 13(1), 30-42. 
[26] Rémy, P., and P.-M. Leroy. (2016). Comment explorer l'album jeunesse? Floreffe, Belgique: Editions Atzeo.

[27] Seaborn, K., \& Fels, D. I. (2015). Gamification in theory and action: A survey. International Journal of human-computer studies, 74, 14-31.]

[28] Shin, J., Dronjic, V., \& Park, B. (2019). The interplay between working memory and background knowledge in L2 reading comprehension. TESOL Quarterly, 53(2), 320-347.

[29] Siemens, G. (2017). Connectivism. Foundations of Learning and Instructional Design Technology.

[30] Strauss, A., \& Corbin, J. (1998). Basics of qualitative research techniques. Thousand Oaks, CA: Sage publications.

[31] Sweetser, P., Johnson, D., \& Wyeth, P. (2012). Revisiting the GameFlow model with detailed heuristics. Journal of Creative Technologies, 2012(3), 1-16.

[32] Ting Fang Kai; Tan Kim Hua (2021). Enhancing English Language Vocabulary Learning through Google Translate Mobile Application among Indigenous Learners. Journal of Education and e-Learning Research, 8(2): 143-148.

[33] Van Zeeland, H., \& Schmitt, N. (2013). Lexical coverage in L1 and L2 listening comprehension: The same or different from reading comprehension?. Applied Linguistics, 34(4), 457-479.

[34] Vorderer, P., Hartmann, T., \& Klimmt, C. (2003). Explaining the enjoyment of playing video games: the role of competition. In Proceedings of the second international conference on Entertainment computing: 1-9.

[35] Wiebe, E. N., Lamb, A., Hardy, M., \& Sharek, D. (2014). Measuring engagement in video game-based environments: Investigation of the User Engagement Scale. Computers in Human Behavior, 32, 123-132.

[36] Zou, B., \& Li, J. (2015). Exploring Mobile Apps for English Language Teaching and Learning. Research-publishing. Net. In Proceedings of 2015 EUROCALL Conference.

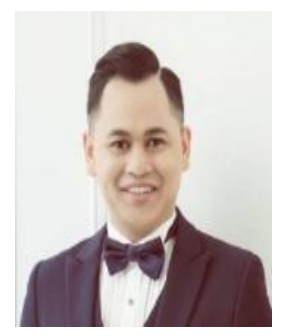

Philip Wilson John was born in Sarikei and raised in Saratok, Sarawak. He graduated from Universiti Kebangsaan Malaysia and his master dissertation is on Teaching English as a Second Language (TESL). He works as an English Lecturer at the Faculty of Education, Management and Science University College Sarawak. His main research interests are teaching and learning in ESL context, particularly on the development of ESL vocabulary. He has published an article in Creative Education and presented in local and international conferences on ESL.

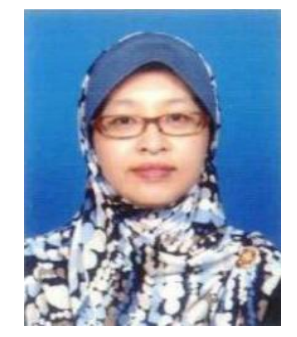

Maslawati Mohamad was born in Johor, Malaysia. She graduated from Universiti Kebangsaan Malaysia and her $\mathrm{PhD}$ is on Teaching English as a Second Language (TESL). Currently, she is a senior lecturer at the Faculty of Education, Universiti Kebangsaan Malaysia. Her main research interests are innovations in teaching and learning in ESL context, Teaching Reading in ESL context and English for Specific Purposes. Currently she has published 101 journal articles including 30 Scopus articles, 55 proceedings, six book chapters and a book. She is also a reviewer for a few international journals and an editor for a local journal.

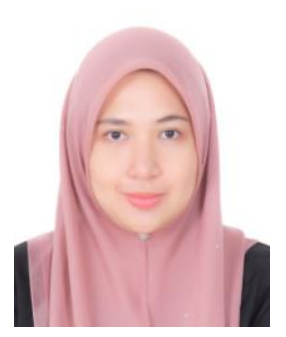

Siti Nur Diyana Mahmud is a senior lecturer at the STEM Enculturation Research Center, Faculty of Education, Universiti Kebangsaan Malaysia. Her expertise is in Environmental Education and Science Education. She holds a PhD in Environmental Education from the University of Queensland Australia. Her research interests are in teaching and learning innovation in Science and Environmental Education, environmental citizenship, and science teacher education. She is the editor and advisor to the local journals and reviewers to international and local journals. She is also a trainer for local STEM teachers.

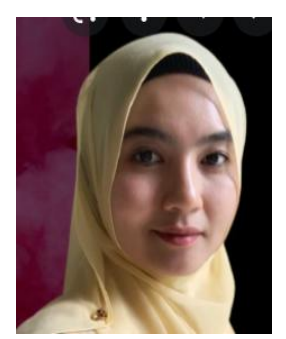

Nurul 'Izzati Md Fuad was raised in Kuala Lumpur, Malaysia. She graduated from Victoria University of Wellington, New Zealand and her PhD is on Teaching English as a Second Language (TESL). Currently, she is a lecturer at the International Languages Teacher Training Institute, Kuala Lumpur, Malaysia. Her main research interests are Teaching Speaking in ESL context, online learning and literature. She had published articles in SCOPUS journals and presented in international conferences on ESL. 